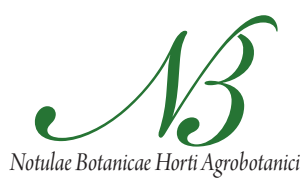

Cluj-Napoca

\title{
Crop Response to Glyphosate Trimesium Sulphosate
}

\author{
Danijela PAVLOVIC ${ }^{1 *}$, Sava VRBNICANIN², Carl REINHARDT ${ }^{3}$ \\ ${ }^{1}$ Institute for Plant Protection and Environment Belgrade, Teodora Drajzera 9, Belgrade, Serbia; dulekaca@yahoo.com (*corresponding author) \\ ${ }^{2}$ University of Belgrade, Faculty of Agriculture, Nemanjina 6, Belgrade, Serbia; sava@agrif.bg.ac.rs \\ ${ }^{3}$ University of Pretoria, Pretoria 0002, Republic of South Africa; dr.charlie.reinhardt@gmail.com
}

\begin{abstract}
Glyphosate may cause injury to non-target plants. The first detectable symptom after glyphosate treatment is the growth inhibition, followed by noticeable yellowing (chlorosis) of the treated tissue. Five to ten days after the treatment, the chlorosis turns into necrosis and the plants begin to die. Greenhouse research was conducted in 2007 to investigate the response of glyphosate resistant (GR) soybeans PAN 520 line and non-glyphosate resistant EGRET line of soybeans to glyphosate trimesium sulphosate and to evaluate soybeans injury to help in weed resistance detection. The methods used to detect changes were dose response test, HPLC measurement based on glyphosate induced accumulation of shikimate, and morpho-anatomical changes (light and electron microscopy). Damaged chloroplasts are a clear indication of a glyphosate injury. If the injury rating is related to increased shikimate levels, there is greater certainty that differences among biotypes are due to glyphosate tolerance.
\end{abstract}

Keywords: Glyphosate, morpho-anatomical injury, shikimate, soybean

\section{Introduction}

A comparison of transgenic versus conventional soybeans reveals that transgenic glyphosate-tolerant soybeans allows both the simplification of weed control and greater work flexibility. Cropping transgenic soybeans also fits well with conservation tillage. Transgenic soybeans has an economic margin similar to conventional soybeans, despite a higher seed cost (Bonny, 2008). Reports stated that over 12 million hectares of cropland producing soybeans were infested with glyphosate resistant weeds in 2010. Across the major resistant weed species, almost 37 million hectares were impacted (Greenpeace summary, 2013). Weed control will continue to be an important component in crop production if high yields and the quality of the crops are to be maintained. High efficacy in weed control today, as it has been for the last 50 years, is achieved through herbicide applications. The most widely used herbicide with consistent weed control is glyphosate (Giesy et al., 2000; Williams et al., 2000). It is the world's most important herbicide because it is versatile, it controls a wide spectrum of annual and perennial weeds in no-till agriculture, orchards, forestry and genetically modified crops such as maize, soybeans, cotton, etc. It is also successfully used as a "burn down" treatment before no-till planting and can be applied alone and in a tank mix (Buhler and Werling, 1989). In the beginning a smaller amount of herbicide was used. This amount increased from 2002 and today the success of transgenic soybeans for farmers has led to a higher use of glyphosate as a replacement for other herbicides. This has in turn led to a decline in its effectiveness (Bonny, 2008).
The first detectable symptom after glyphosate treatment is growth inhibition, followed by a noticeable yellowing (chlorosis) of treated tissue. Five to 10 days after the treatment, the chlorosis turns into necrosis and the plants begin to die (Monaco et al., 2002). Glyphosate disrupts chloroplasts, cell membranes, cell walls, alters protein and nucleic acid synthesis, inhibits photosynthesis (Hoagland and Duke, 1982) and reduces chlorophyll content (Lee, 1981). Glyphosate binds to 5-enolpyruvylshikimate-3-phosphate synthase (EPSPS) enzyme (EC 2.5.1.19), which consequently inhibits the biosynthesis of the aromatic amino acids, tryptophan, tyrosine and phenylalanine (Siehl, 1997). With the inhibition of the EPSPS, shikimate-3 phosphate accumulates and is cleaved to shikimate in the tonoplast or vacuole (Hollander-Czytko and Amrhein, 1983). An assay measuring shikimate provides empirical evidence for glyphosate drift in addition to visual or morfo-anatomical symptoms (Burke et al., 2005).

In this study, we examined effects of glyphosate-trimesium sulphosate on anatomical properties and shikimate accumulate, to explain differences between GR and conventional non herbicide resistant soybeans.

\section{Materials and methods}

\section{General procedures}

Experiments were conducted in 2007 at the University of Pretoria (South Africa) in the greenhouse and laboratory. Seeds of soybean varieties: genetically modified PAN 520 (GR; seed provided by Syngenta, South Africa) and susceptible EGRET (S) were planted in 1L pots. Pots were 
filled with soil from a typical field for the South African region. At the cotyledon plant growth stage pots were thinned to 3 plants per pot. Plants were then placed in the greenhouse at an average $22.8 / 10.5^{\circ} \mathrm{C}$ (day/night) temperature, $54.6 \% \mathrm{RH}$, under 12:12 h light: dark period. For better $\mathrm{N}$ fixation soybean seeds were inoculated with Bradylizobium japonicum $\left(6.5 \times 10^{8}\right.$ live cells $\mathrm{g}^{-1}, 100 \mathrm{~g}$ seed with $400 \mathrm{mg}$ inoculums). After planting, $400 \mathrm{ml}$ of tap water were added to each pot and plastic bags were tied above to keep the moisture until the cotyledon growth stage. The plants were watered every other day with tap water and every 15 days $200 \mathrm{ml}$ of nutrient solution (calcium nitrate: $\mathrm{CaO}-19.5 \%$ and $\mathrm{NO}_{3}-15.5 \%$ and potassium sulfate: $\mathrm{K}_{2} 0-42 \%$ and S-18.5\%) were added. Nutrient solutions were prepared by dissolving $7.5 \mathrm{~g}$ calcium nitrate and $32 \mathrm{~g}$ of potassium sulfate in $50 \mathrm{~L}$ of water. In our experiments soybean plants were treated with six doses of glyphosate trimesium sulphosate $\left(500 \mathrm{~g} \mathrm{~L}^{-1}\right): 0.5 \mathrm{~kg}$ a.i. $\mathrm{ha}^{-1}, 1 \mathrm{~kg}$ a.i. $\mathrm{ha}^{-1}, 2 \mathrm{~kg}$ a.i. ha ${ }^{-1}, 3 \mathrm{~kg}$ a.i. ha ${ }^{-1}, 4 \mathrm{~kg}$ a.i. ha ${ }^{-1}$ and $5 \mathrm{~kg}$ a.i. $\mathrm{ha}^{-1}$ plus untreated control. Treatments were performed 28 days after planting (at first trifoliate growth stage, $\mathrm{BBCH}$ 11 ) using the indoor hand sprayer equipped with a RSMM $110^{\circ} / 04$ nozzles and applying $300 \mathrm{~L}$ of water per ha at $276 \mathrm{kPa}$. The experimental design used was completely randomized design, with two replications. The pots were harvested 17 days after application (DAA). The plants were then oven-dried $\left(75^{\circ} \mathrm{C}\right)$ for $48 \mathrm{~h}$ to determine the dry weight. For monitoring morpho-anatomical changes we used the glyphosate trimesium sulphosate at doses of $0.05,0.1$ and $0.2 \mathrm{~g}$ a.i. $\mathrm{m}^{-2}$ in $40 \mathrm{ml}$ of water. Application was made by dipping one half of one leaf per plant per each herbicide dose. Samples were collected 3, 7 and 24 hours after application (HAA). For measuring shikimate accumulation three weeks old plants were used. Plants were sprayed with $1 \mathrm{~kg}$ a.i.ha ${ }^{-1}$ dose of herbicide. Samples were collected from treated and untreated plants of both varieties at 2, 4 and 6 DAA.

\section{Extraction of shikimate}

Plant material was ground in liquid nitrogen by mortar and pestle. About $1.5 \mathrm{~g}$ of ground material was mixed with $10 \mathrm{ml}$ of $1 \mathrm{M} \mathrm{HCl}$ and shaken for $24 \mathrm{~h}$. The $\mathrm{pH}$ was adjusted with $1 \mathrm{M} \mathrm{NaOH}$ and $0.1 \mathrm{M} \mathrm{NaOH}$ to $\mathrm{pH}=3.0$ - 3.5. After that, filtration was conducted and supernatant was refrigerated at $4{ }^{\circ} \mathrm{C}$ until the analysis. Analysis of shikimate (HPLC) was performed by using Mueller et al. (2003) method. Material extracted as described above was centrifuged at $15.000 \mathrm{~g}$ for $5 \mathrm{~min}$ to remove any particulate matter. An aliquot $(20 \mu \mathrm{l})$ of the supernatant was injected into water HPLC (Hewlett Packard Agilent 1100 series, DAD (Diode Array Detector), Lune- $\mathrm{NH}_{2}$, column diameter 5 $\mu \mathrm{l}$, flow $\left.1 \mathrm{ml} \mathrm{min}^{-1}\right)$. The retention time of shikimate was approximately $7 \mathrm{~min}$.
Microscopy (TEM - Transmission electron microscopy and LM-Light microscopy)

Samples were collected 3, 7 and 24 HAA. Sample preparation for TEM and LM microscopy was done according to Glauert (1975). Pieces about 2-4 $\mathrm{mm}^{2}$ were cut from the first true developed trifoliate. Samples were fixed by immersion in glutaraldehyde $(2.5 \%$ glutarat aldehide in $0.075 \mathrm{M}$ phosphate buffer, $\mathrm{pH} 7.4$ ) for $24 \mathrm{~h}$ at $4{ }^{\circ} \mathrm{C}$. Samples were then rinsed $(3 \times 10 \mathrm{~min})$ in fresh phosphate buffer and fixed in $0.5 \%$ water solution of osmium tetraoxide (1-2 h), and rinsed 3 times with distilled water. Dehydration was done in increasing concentrations of ethanol $(30 \%, 50 \%, 70 \%, 90 \%, 3 \times 100 \%)$ for $30 \mathrm{~min}$. Samples were then infiltrated in 50\% Quetol for 1 hour and placed in plastic wells filled with Quetol (100\%) for polymerization. Polymerization was done in an oven at $60^{\circ} \mathrm{C}$ for 39 $\mathrm{h}$, and quetol blocks were cut on microtome (LEICA SM $2000 \mathrm{R}$ ). The final steps of sample preparation for microscopy were done according to the procedure developed by Coetzee and Van der Merwe (2007).

\section{Transmission electron microscopy (TEM)}

Ultra-thin cuts of leaf samples were placed on a mesh $(\varnothing 3 \mathrm{~mm})$ and fixed with $4 \%$ uranil acetate $(10 \mathrm{~min})$ and Reinold's acid ( $2 \mathrm{~min}$ ) followed by rinsing $20 \times$ in each of 3 glasses filled with distilled water. Samples were examined under a transmission electron microscope (Philips EM 301 transmission electron microscope, Eindloven, Netherlands).

\section{Light microscopy (LM)}

Leaf cuts $(1-5 \mu \mathrm{m})$ were placed on a microscope glass in a drop of water, dyed with Toluidine blue, dried, covered with oil (Zeiss, Immersol, 518N) and covered with the cover glass. Samples were examined under the light microscope (Nikon Optiphod-Nikon Instech Co., Kanagawa, Japan).

\section{Statistical analysis}

Statistical analysis was performed with the SigmaPlot 4.0 software (1997). The experimental results of microscopy studies were examined visually. Lethal dose curves were fitted according to the following nonlinear regression model accounting for harmful effects proposed by Brain and Cousens (1989): $Y=c+\{[(d-c)+(k x)] /[1+$ $\left.\left.(\mathrm{x} / \mathrm{g})^{\mathrm{b}}\right]\right\}$; where: $\mathrm{Y}-\%$ growth, $\mathrm{c}$-average plant response to high herbicide application rate, $\mathrm{d}$-average plant response to application rates close to zero, b-slope of the best fitted line, g-herbicide dose causing the effect between $\mathrm{c}$ and $\mathrm{d}, \mathrm{x}$ herbicide application rate, and $k$-the initial rate of increase at low doses. Index of resistance (IR) was calculated as $\mathrm{LD}_{50}$ of the resistant population / $\mathrm{LD}_{50}$ of the susceptible population. 
584

Results

\section{Dose response test}

Differences in response to herbicide doses between varieties were observed through dry weight data (Tab. 1, Fig. 1 a,b). The IR showed that the GR was significantly more tolerant than the $S$ variety. Visual evaluation showed injury (17 DAA) in both varieties. Symptoms were temporary in GR, and in $S$ plants injury lead to plant decay. In the $S$ plants, $0.5 \mathrm{~kg}$ a.i. ha $^{-1}$ caused curling of leaves which turned into chlorosis and necrosis at four times this rate. Fifty percent of the plants were dead after application of $0.5 \mathrm{~kg}$ a.i. ha ${ }^{-1}$ and almost $100 \%$ of the plants were dead after the application of $1 \mathrm{~kg}$ a.i. $\mathrm{ha}^{-1}$ of the herbicide, respectively. Contrary, the GR showed the first symptoms at $2 \mathrm{~kg}$ a.i. ha ${ }^{-1}$ as slight chlorosis, brown spots, speckling and curling of the leaves.

\section{Effect of glyphosate on morpho-anatomical changes in soybeans leaf}

Tab. 1. $\mathrm{LD}_{50}$ and IR for glyphosate based on dry weight of soybean varieties

\begin{tabular}{cccc}
\hline $\begin{array}{c}\text { Soybean } \\
\text { variety }\end{array}$ & LD50 & CI & IR \\
\multicolumn{5}{c}{ kg a.i. ha $^{-1}$} \\
Experiment I \\
S & 0.107 & 0.103 \\
GR & 0.929 & 0.336 & 8.69 \\
S & \multicolumn{2}{c}{ Experiment II } \\
GR & 0.91 & 0.77 \\
\hline
\end{tabular}

$\mathrm{CI}$ - confidence interval 0.05 for $\mathrm{LD}_{50}, \mathrm{IR}$ - index of resistance

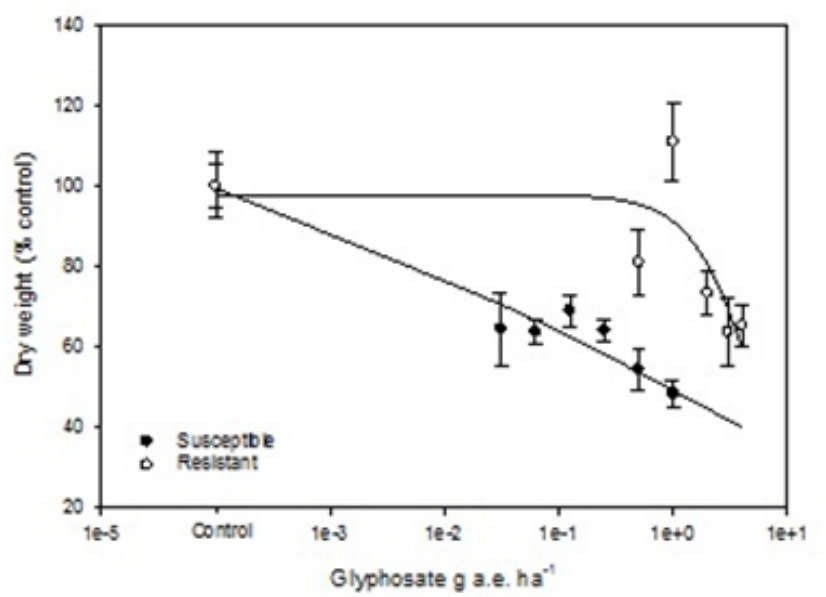

Fig. 1a. Dry mass of susceptible and glyphosate resistant soybean plants at different glyphosate doses; Experiment I

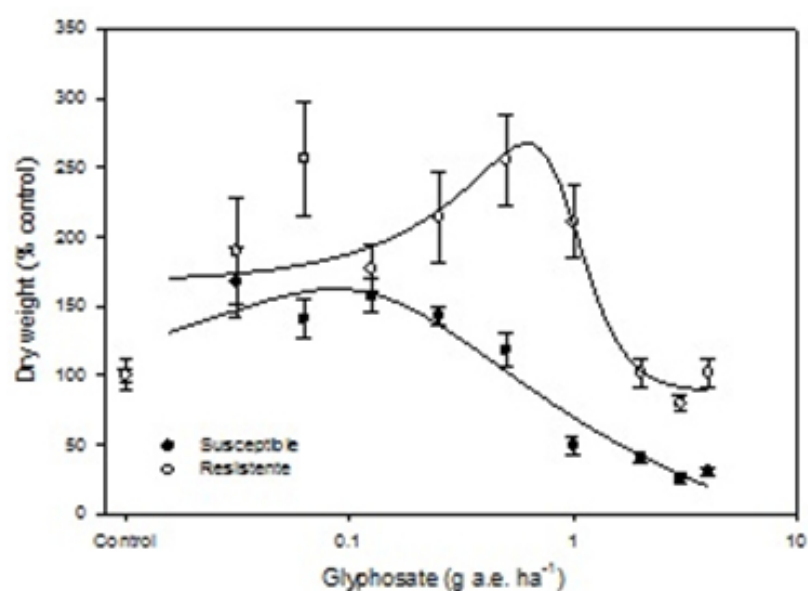

Fig. 1b. Dry mass of susceptible and glyphosate resistant soybean plants at different glyphosate doses; Experiment II

Effects of glyphosate on leaf anatomy of GR and S varieties were observed. Deformations, wrinkling and changes of shape in leaf cells were observed less than $24 \mathrm{HAA}$ of 1 and $2 \mathrm{~kg}$ a.i. ha ${ }^{-1}$ in $S$ plants of soybeans (Fig. 2b) vs GR (Fig. 2a). Symptoms on leaves of the GR plants were similar. They were expressed at lower levels than in $S$ plants and appeared only after the application of the highest dose (2 $\mathrm{kg}$ a.i.ha-1). Brown spots were shown only on GR soybeans leaves at $2 \mathrm{~kg}$ a.i. ha ${ }^{-1}$ of herbicide a couple of days after the treatment (Fig. 2c). Symptoms on the GR vs. S plants were temporary.

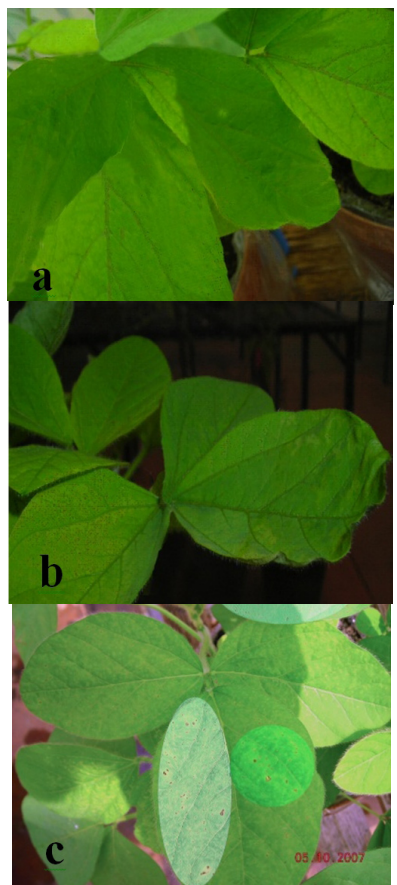

Fig. 2. Effects of glyphosate ( $2 \mathrm{~kg}$ a.i.ha $\left.{ }^{-1}\right)$ during the first 24 HAA on soybean plants: a) GR variety; b) S variety; c) brown spots on GR variety 
Anatomical alterations were more intense in $S$ than in GR cells. LM and TEM showed different levels of damage in leaf tissue and cells at different doses of glyphosate.

\section{Light microscopy}

The observations on healthy tissue of both varieties are illustrated in Fig. 3a and 3e. The upper surface of untreated leaves at 0 -h exhibited a cobblestone structure of elongated and gently contoured epidermal cells separated by depres sions. The upper and lower epidermal cells had thick walls. Mesophyll cells contained abundant organelles, including many chloroplasts and central vacuoles.

Damage on the upper epidermis and palisade tissue as well as changes in pith tissue were noticeable at $24 \mathrm{HAA}$ of $S$ leaves treated with 0.5 and $1 \mathrm{~kg}$ a.i. ha ${ }^{-1}$ of the herbicide (Fig. 3b, c), while cytolisis, pycnotic clumping and general structural disorganization of the stoma were recorded at the highest treatment rate (Fig. 3d).

In contrast, structural damages to GR leaves were minimal (Fig. 3f, g). Compared to S, GR leaves appeared unaf-

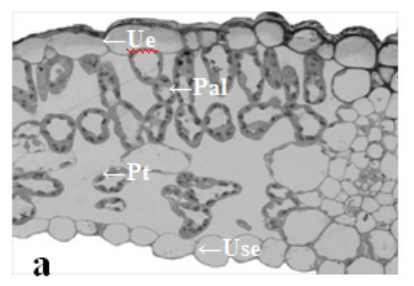

$0 \mathrm{~h}$ time, Control, enlargement $40 \mathrm{x}$,

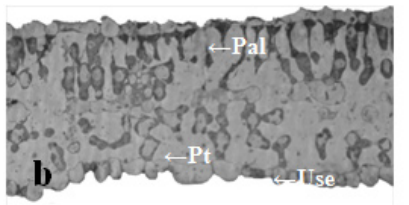

$24 \mathrm{HAA}, 0.5 \mathrm{~kg}$ a.i. ha- ${ }^{-1}$, enlargement $20 \mathrm{x}$

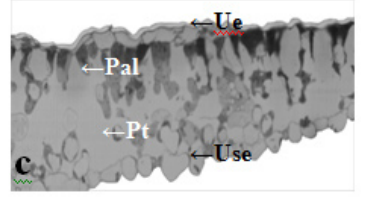

24 HAA, $1 \mathrm{~kg}$ a.i. ha- ${ }^{-1}$, enlargement $20 \mathrm{x}$

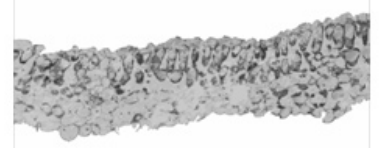

\section{d}

24 HAA, $2 \mathrm{~kg}$ a.i. ha- ${ }^{-1}$, enlargement $20 \mathrm{x}$

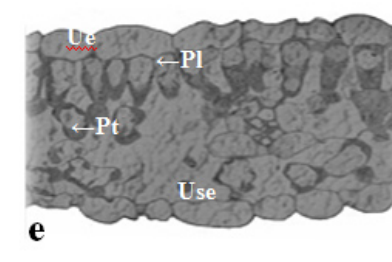

$0 \mathrm{~h}$ time, Control, enlargement $40 \mathrm{x}$

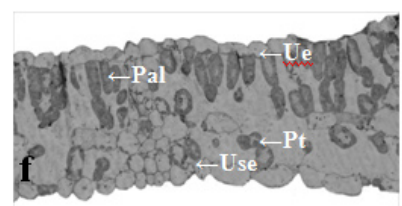

$24 \mathrm{HAA}, 0.5 \mathrm{~kg}$ a.i. ha- ${ }^{-1}$, enlargement $20 \mathrm{x}$

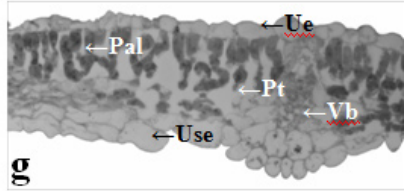

$24 \mathrm{HAA}, 1 \mathrm{~kg}$ a.i. ha ${ }^{-1}$, enlargement $20 \mathrm{x}$

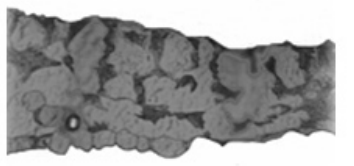

h

24 HAA, $2 \mathrm{~kg}$ a.i. ha ${ }^{-1}$, enlargement $20 \mathrm{x}$

Fig. 3. Light micrographs of cross sections of leaves of the $S$ (a, $\mathrm{b}, \mathrm{c}$ and $\mathrm{d}$ ) and GR (e, f, g and $\mathrm{h}$ ) varieties at various times after treament with different rates of a commercial glyhphosate formulation at half leaf stage of growth showing effects on upper (Ue) and lower (Use) epidermal cells, palisade (Pal) and pith $(\mathrm{Pt})$ tisue
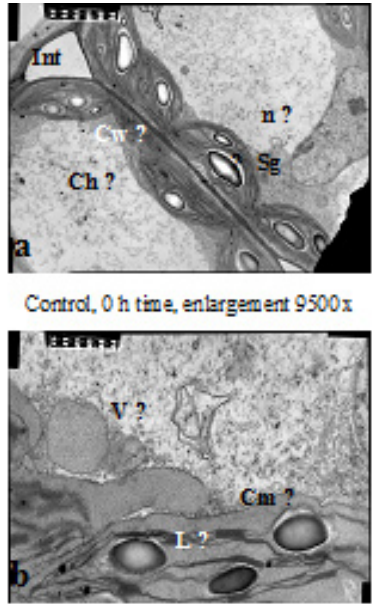

24 HAA, $0.5 \mathrm{~kg}$ ai ha ${ }^{-1}$, enlargement 9500

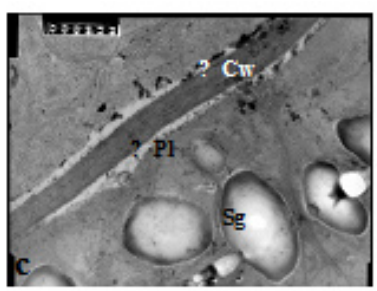

24HAA, $1 \mathrm{kga}$ i ha ${ }^{-1}$, enlargenent $9500 \mathrm{x}$

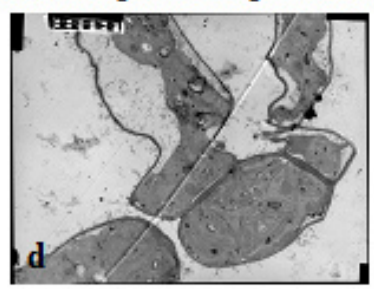

7 HAA, 2 ig ai ha ${ }^{-1}$, enlargement $4300 \mathrm{x}$

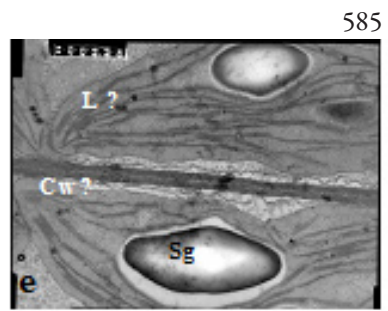

Control, 0 h time, enlargement $28000 x$

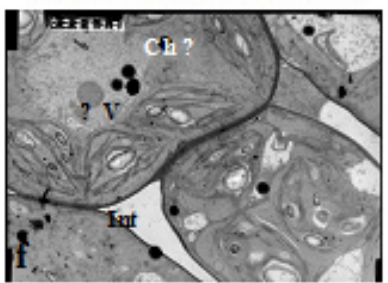

24 HA.A, $0.5 \mathrm{~kg}$ ai ha ${ }^{-1}$, enlargement $9500 \mathrm{x}$

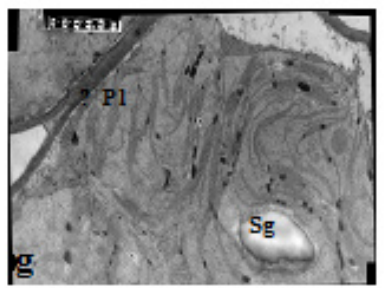

24HAA, 1 lg ai ha ${ }^{-1}$, enlargement $9500 \mathrm{x}$

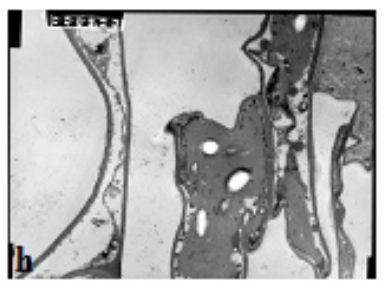

7 HAA, 2 sg ai ha ${ }^{-1}$, enlargement $4300 \mathrm{x}$
Fig. 4. Transmision electron micrographs of cross sections of leaves of the $S$ (a, b, c and d) and GR (e, f, g and h) varieties at various times after treament with different rates of a commercial glyhphosate formulation at half leaf stage of growth showing effects on chloroplasts $(\mathrm{Chl})$, cell membrane $(\mathrm{Cm})$, lamelas $(\mathrm{L})$ and product of photosynthesis, starch granules $(\mathrm{Sg})$

fected at $24 \mathrm{HAA}$ of $0.5 \mathrm{~kg}$ a.i. ha ${ }^{-1}$ of the herbicide (Fig. 3f). $1 \mathrm{~kg}$ a.i. ha ${ }^{-1}$ of glyphosate caused no damage on upper and under epidermal cells, mesophyll and vascular bonds (Fig. 3g), but palisade and pith tissue cells appeared damaged at $2 \mathrm{~kg}$ a.i. ha ${ }^{-1}$ at $24 \mathrm{HAA}$ (Fig. 4h) like the cells of S plants (Fig. 3d). Alterations in epidermal cells indicate the susceptibility of the variety even to low glyphosate rates (Fig. 3b).

\section{Transmission electron microscopy}

Electron micrographs of cross sections of both varieties are shown in Fig. 4. Changes in $S$ plants were shown as significant damage of lamellas, branches and chloroplast membranes and a number of chlorophyll grains were significantly reduced. Changes in GR were hardly noticeable. 
586

Healthy tissues of both varieties are illustrated in Fig. $4 \mathrm{a}$ and 4e. Thick cell walls, a normal elliptical shape of chloroplasts with starch granules, and non-affected lamellas in untreated leaves of both varieties are illustrated in Fig. 4a,e. At $0.5 \mathrm{~kg}$ a.i. ha ${ }^{-1}$ of glyphosate wrinkling and the destruction of chloroplast lamellas occur and intercellular spaces between the cells can't be seen while formed vesicles in cytoplasm of $S$ plants (Fig. $4 b$ ) can. In addition, no symptoms in cells of GR plants (except very small vesicles) were noted (Fig. 4f). A high level of damage of chloroplasts (Fig. 4c) and plasmalema separated from the cell wall vs normal cells in GR plants are shown in Figure 4g. Low effects of herbicide application on cells of GR plants are shown as disintegrated chloroplasts and starch granules (Fig. 4g). These alterations would correspond to damages observed in palisade and pith cells (Fig. 3c, g). At $2 \mathrm{~kg}$ a.i. ha ${ }^{-1}$ of herbicide application the cytolysis and total tissue damages in the leaf anatomy of both varieties were observed (Fig. 4d, h) and corresponded to the alterations observed with the LM (Fig. 3d, h).

\section{Shikimate accumulation due to glyphosate toxicity}

The control plants of both varieties had very small amounts of shikimate (GR $-0.129 \mathrm{mg} \mathrm{g}^{-1}, \mathrm{~S}-0.117 \mathrm{mg} \mathrm{g}^{-1}$ fresh weight) and this confirmed the validity and sensitivity of this method. In contrast, the concentration of shikimate increased rapidly in the glyphosate treated $S$ plants.

After glyphosate treatment the concentration of shikimate reached $3.591 \mathrm{mg} \mathrm{g}^{-1}$ fresh weight in $S$ plants and $0.243 \mathrm{mg} \mathrm{g}^{-1}$ fresh weight in GR 6 DAA. Amount of shikimate in treated $S$ plants rapidly increased: 19.6 fold (second day), 28.4 fold (fourth day) and 30.7 fold (sixtieth day) compared with untreated control vs GR. Statis-

Tab. 2. ANOVA differences in the amount of shikimic acid based on the sampling date

\begin{tabular}{lcccc}
\hline & \multicolumn{2}{c}{ S soybean } & \multicolumn{2}{c}{ GR soybean } \\
C-2 day & 0.0028 & ${ }^{* * *}$ & 0.311 & NS \\
\hline C-4 day & 0.000044 & ${ }^{* * *}$ & 0.026 & $*$ \\
\hline C-6 day & 0.000014 & ${ }^{* * *}$ & 0.476 & NS \\
\hline 2-4 day & 0.096 & NS & 0.152 & NS \\
2-6 day & 0.0379 & ${ }^{*}$ & 0.733 & NS \\
4-6 day & 0.653 & NS & 0.08 & NS \\
\hline
\end{tabular}

Confidence interval 0.05, C-control, $\mathrm{P}<0.0001^{* * * *}, \mathrm{P}<0.001^{* * *}, \mathrm{P}<0.01^{* *}$, $\mathrm{P}<0.05^{*}$, NS- non significant differences, $\mathrm{S}$-susceptible variety, GRglyphosate resistant variety, C-control

tical analysis (ANOVA) confirmed significant differences in the amounts of shikimate sampled at 2, 4 and 6 DAA (Tab. 2).

Statistical analysis of GR plants showed no significant differences between the data sampled at 2, 4 and $6 \mathrm{DAA}$ except between untreated and treated plants at 4 DAA (Tab. 2). From 2 to $4 \mathrm{DAA}$ in the GR plants the amount of shikimate increased 3.9 fold and from 4 to 6 DAA de- creased 1.9 fold, but these changes were not statistically significant (Tab. 2).

\section{Discussion}

At first glance susceptible and glyphosate resistant varieties of soybeans look similar, almost the same, but their reaction to different doses of glyphosate was different. We started with the hypothesis that every applied dose of herbicide can cause some level of damage to leaves in case of non-target application of herbicide, independently of the soybeans variety. Every change to the cuticle and epidermis will affect the passive way for glyphosate absorption (Feng et al., 2003), and further effects will depend on plant genetics and its fitness. The flattening of the epidermal surface (observed $24 \mathrm{HAA}$ in our experiments) is likely due to turgidity loss in the epidermal cells, leading to the formation of depressions and peaks (Fig. 3b, d). Damage to epidermal cells and cells in general of $S$ plants after the application of $0.5 \mathrm{~kg}$ a.i. ha ${ }^{-1}$ of glyphosate, confirm the susceptibility of these plants (Fig. 3b). In addition, changes appeared on palisade cells and chloroplasts. Similar results were reported by Azevedo (1995) in the response to pollutants in Glycine max. Similarly Santos et al. (2007) observed damages on epidermal cells of Eucaliptus urograndis. At the rate of $1 \mathrm{~kg}$ a.i. ha ${ }^{-1} 24 \mathrm{HAA}$ cells of palisade tissue were disorganized in $S$ plants (Fig. 3c), and chloroplasts were destroyed (Fig. $3 \mathrm{c}$ and $4 \mathrm{c}$ ). Ryerse et al. (2004) concluded that formulation and surfactant can affect crop yield and efficacy of different herbicide formulations containing the same active ingredient. Damage to chloroplasts in $S$ plant cells explain chlorotic symptoms and reduced photosynthesis vs GR plants. Detected symptoms in our experiments (chlorosis, necrosis, brown spots, wrinkling of the leaves etc., Fig. 5) are consistent with earlier descriptions of glyphosate damage to soybeans at comparable growth stages (Zobiole et al., 2011). These clear pictures we expected in case of weed resistance. However, our tested C. bonariensis population did not show visual differences in sensitivity to glyphosate. Lethal dose for susceptible population of $C$. bonariensis was $0,119 \mathrm{~kg}$ a.i. $\mathrm{ha}^{-1}$ and calculated IR was 1,25 .

Some researchers also indicated that GR soybeans has acceptable tolerance to POST applications of glyphosate,

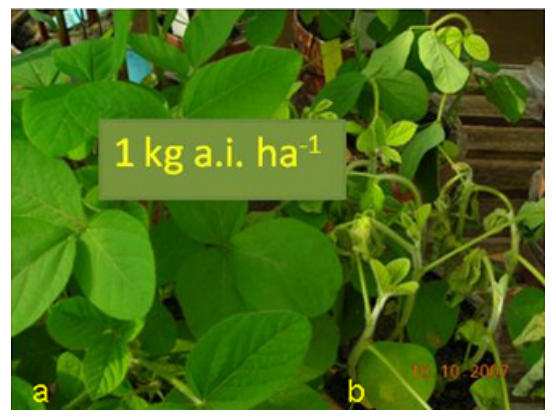

Fig. 5. Response to glyphosate $1 \mathrm{~kg}$ a.i.ha ${ }^{-1}$; a) GR; b) S 
although temporary injury symptoms of chlorosis, dark spotting and necrosis have been reported (Krausz and Young, 2001). Al-Khatib and Peterson (1999) reported that glyphosate at 280 g.a.i.ha ${ }^{-1}$ applied at V3 growth stage caused transient injury to conventional soybeans but did not reduce yield. Insertion of a gene encoding a glyphosate-insensitive EPSPS into soybeans (Padgette et al., 1995) enables GR soybeans to remain almost unaffected upon glyphosate treatment, because the glyphosate insensitive EPSPS allows the plant to meet its needs for the aromatic amino acids. Although GR soybeans may not be totally invulnerable to glyphosate, it generally has a larger margin of safety than typically found with traditional selective herbicides used in soybeans. Potential risks associated with herbicide injury are thus greatly reduced (Padgette et al., 1995). Metabolism of glyphosate in tolerant plants (crop and weed) can explain more or less temporary slight chlorosis, speckling and brown spots in GR (Fig. 2c). According to Duke et al. (2003) amynomethyl phosphonic acid (AMPA) is the main glyphosate metabolite which can cause damage to leaves of glyphosate tolerant soybeans. Reddy et al. (2004) gave similar conclusions, and determined the presence of AMPA in leaves and seeds of soybeans and with that explained the symptoms on GR plant leaves. When comparing the symptoms they determined, changes in GR variety after application of glyphosate came from its metabolite AMPA. This metabolite at $0.12 \mathrm{~kg} \mathrm{ha}^{-1}$ causes chlorosis of GR soybeans. Identification of such alterations would be useful for early detection of injury by glyphosate drift events. Contrary to morphological changes noted 17 DAA of herbicide, anatomical changes in leaf tissue were seen already a few HAA, which would enable the rapid identification of differential sensitivity to herbicides such as glyphosate. In both of the varieties changes were determined at $7 \mathrm{HAA}$ at $2 \mathrm{~kg}$ a.i. ha ${ }^{-1}$ of glyphosate (Fig. $4 \mathrm{~d}, \mathrm{~h}$ ) and $24 \mathrm{HAA}$ at all applied doses of the herbicide in $S$ soybean plants (Fig. 3b, c, d, 4b, c, d). Ryerse et al. (2004) noted dehydration of epidermal cells, partial cytolysis and cytolysis of pith tissue cells by $6 \mathrm{HAA}$ at $740 \mathrm{~g}$ a.i. ha ${ }^{-1}$ glyphosate. In their experiments changes confirmed on all anatomical levels of the leaf were also confirmed in our experiments. Also, Ryerse et al. (2004) determined cell merger at 6 HAA, particular citolysis of epidermal and pith tissue cells. The main differences in reaction between $S$ and GR plants to glyphosate are seen through in chloroplasts. Analysis of leaf sections of $C$. bonariensis showed that lowest dose of glyphosate also caused changes in the tissue: deformations of cellwall, lamelas and chloroplasts and number of chlorophyll grains have decreased (Fig. 6). Coresponding to increasing dose of herbicide the injuries were more prevalent.

Destroyed chloroplasts caused the reduction of photosynthesis and halted plant growth.

Glyphosate caused absorption of $\mathrm{CO}_{2}$ of young leaves in the first 2 HAA, which resulted in changes in shikimate pathway and photosynthesis, and all those effects

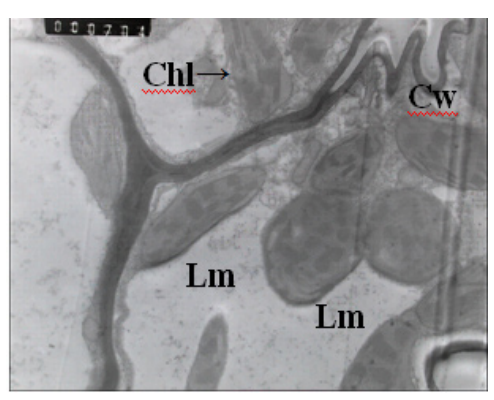

Fig. 6. Leaf section C. bonariensis after $0.5 \mathrm{~kg}$ a.i. ha ${ }^{-1}$ glifosate trimesium sulphosate: cell wall $(\mathrm{Cw})$, chloroplast $(\mathrm{Chl})$, lamelas (Lm) (TEM, enlargement 7500x), 24 HAA

together inhibited plant growth. Similarly, Gougler and Geiger (1984) concluded that when low productivity of photosynthesis is measured after glyphosate application, plants will die. All determined symptoms in our experiments confirmed effects of MOA (mode of action) of glyphosate. These experiments showed the importance of leaf micro-morphological studies in characterization of injuries caused by glyphosate drift, prior to visual damage (Santos et al., 2007). It is important to know that when applied foliarly glyphosate is very mobile in the plant, and is rapidly distributed through symplastic route down to the roots and meristem (Bromilow and Chamberlain, 2000). When glyphosate is applied at sub-lethal doses the product can result in injuries developing from the younger to the older parts of the plant (Santos et al., 2007).

The small amount of shikimate in untreated plants confirmed that the amount of shikimate is not related to the resistance or susceptibility of the plants. This method is used as an early and highly sensitive indicator of glyphosate effects on sensitive plants (Komossa, 1992). Changes in the amount of shikimate in treated plants vs control plants were significant for $S$ plants and not significant for GR plants, except at 4 DAA (Tab. 2). Other researchers observed a decreased concentration of shikimate in GR soybeans (Singh and Shaner, 1998) and in Abutilon theophrasti Medik. (Becerril et al., 1989). This observation is most likely due to the metabolism of shikimate in resistant plants as the plant recovers from the initial injury which is not the case for susceptible plants. In contrast, the concentration of shikimate increased from 2-6 DAA in non GR plants of soybeans.

Applied herbicide caused stress to the plants of both varieties, but GR plants did not show the symptoms. One of the explanations may be that in GR plants the metabolism is activated or that the production of insensitive EPSPS has increased. This theory is based on the fact that the accumulated shikimate binds with the alternative type of EPSPS which will discharge, and on the possibility that other enzymes are also present in the cells (GOX enzymes) which can decompose herbicides like glyphosate (Mannlerof et al., 1997). These observations demonstrate that these soybean varieties differ in susceptibility to the MOA of glyphosate, since accumulation of shikimate 
588

following glyphosate treatment is an accepted diagnostic tool of glyphosate toxicity in susceptible plants (Mueller et al., 2003). Analisys of shikimate amount was not precise enough in case of $C$. bonariensis determination of resistance. The amounts of shikimate in control plants were about $0,313 \mathrm{mg} g$ fresh weight ${ }^{-1}$, however in treated plants were under the limit of detection. Expected and clear differences like in soybeans tissue were not found in tested populations of $C$. bonariensis. In contrast, experiments with populations of $C$. canadensis give clear differences in sensitivity to glyphosate by shikimate method. The tolerance of the GR plants is consistent with the presence of a mutant EPSPS that is resistant to glyphosate inhibition (Powles and Preston, 2006). The discrepancy of shikimate accumulation can be used to differentiate between glyphosate $S$ and $R$ plants, although it is not an indication of the mechanism responsible for such resistance (Mueller $e t$ al., 2003; Pavlovic et al., 2011). HPLC determination of shikimate level can be conducted at different plant growth stages even on dead plant material (Singh and Shaner, 1998), which is very useful, because drift injury from glyphosate may occur at any time during the growing season. In general, plant health was affected in all treatments that caused several symptoms. In this study, we noted morpho-anatomical changes in soybean leaves at 7-24 HAA of glyphosate-trimesium sulphosate, but the conclusion depends on glyphosate doses. Glyphosate-trimesium sulphosate caused some damage to the epidermis, cuticle and wax, but similar symptoms and weed control have been reported with trimethyl-sulfonium salt of glyphosate and glyphosate-isopropylamine (Carlson and Burnside, 1984). In addition, some researchers reported similar absorption and translocation of these to salts of glyphosate in Setaria faberi Herrm. and Abutilon theoprasti Medic. (Satchivi et al., 2000).

Damaged chloroplasts are a clear indication of a glyphosate injury and therefore can be used in determination of susceptibility to glyphosate.

These results suggest the in vivo assays can detect not only target site based resistance but also resistance from limited absorption and translocation of glyphosate. Shikimate did not accumulate in GR crops that contained an insensitive EPSPS. Shikimate accumulated in C. canadensis suggests that EPSPS was still sensitive to the herbicide. However, at low glyphosate concentrations little or no shikimate accumulated in the $C$. bonariensis potentially because of reduced movement of herbicide to the active site. If the injury rating is related to increased shikimate levels, there is a greater certainty that differences among biotypes are due to glyphosate tolerance. These two assays should have utility in screening other weed populations for resistance to glyphosate.

\section{Acknowledgements}

We thank Syngenta and University of Pretoria, for the invitation to work on this research project, for providing the research site and logistical support. Also thanks to the Ministry of Education and Science of R. Serbia for supporting this research (Projects 31018 and III 46008).

\section{References}

Al-Khati K, Peterson D (1999). Soybean (Glicine max) response to simulated drift from selected sulfonylurea herbicides, dicamba, glyphosate and glufosinate. Weed Technology 13:264-270.

Azevedo AA (1995). Acao do fluor, em chuva simulada, sobre a estrutura foliar de Glycine max (L) Merril. (Tese de Doutorado). Universidade de Sao Paulo, Sao Paulo, 95.

Becerril J, Duk S, Lydon J (1989). Glyphosate effects on shikimate pathway products in leaves and flowers of velvetleaf. Phytochem 28:695-699.

Bonny S (2008). Genetically modified glyphosate-tolerant soybean in the USA: adoption factors, impacts and prospects. A review. Agron Sustain Dev 28(1):21-32.

Brain P, Cousens R (1989). An equation to describe dose responses where there is stimulation of growth at low doses. Weed Research 29:93-96.

Bromilow RH, Chamberlain K (2000). The herbicide glyphosate and related molecules: physicochemical and structural factors determining their mobility in phloem. Pest Manage Science 56:368-373.

Buhler DD, Werling VL (1989). Weed control from imazaquin and metolachlor in no-till soybeans (Glicine max). Weed Science 37:392-399.

Burke IC, Thomas EW, Pline-Srnic AW, Fisher RL, Smith DW, Wilcut WJ (2005). Yield and Physiological Response of Flue-Cured Tobacco to Simulated Glyphosate Drift. Weed Technolgy 19(2):255-260.

Carlson KL, Burnside OC (1984). Comparative phytotoxicity of glyphosate, SC-0224, SC-0545, and HOE-00661. Weed Science 32:841-844.

Coetzee J, Van der Merwe CF (2007). Preparation of biological material for Electron microscopy, Laboratory for Microskopy and Microanalysis, Univesity of Pretoria.

Duke SO, Rimando AM, Pace PF, Reddy KN, Smeda RJ (2003). Isoflavone, glyphosate and aminomethylphosphonic acid levels in seeds of glyphosate-treated soyabean. J Agric Food Chem 51:340-344.

Feng PCC, Chiu T, Sammons RD, Ryerse JS (2003). Droplet size affects glyphosate retention, absorption and translocation in corn. Weed Science 51:443-448.

Giesy JP, Dobson S, Solomon KR (2000). Ecotoxicological risk assesment for Roundup herbicide. Rev Environ Contam Toxicol 167:35-120.

Glauret AM (1975). Practical methods in electron microscopy. North-Holland Publishing, Amsterdam.

Gougler JA, Geiger RD (1984). Carbon partitioning and herbicide transport in glyphosate tretaed Sugar beet. Weed Sci- 
ence 32:546-551.

Greenpeace summary (2013). Glyphosate tolerant crops, in the EU, www.greenpeace.org.

Hoagland RE, Duke OS (1982). Biochemical Effects of Glyphosate [N-Phosphonomethyl)glycine], Biochemical Response Induced by Herbicides 175-205.

Komossa D, Gennity I, Sandermann H (1992). Plant metabolism of herbicides with C-P bonds: glyphosate. Pestic Biochem Physiol 43:85-94.

Krausz RF, Young BG (2001). Response of glyphosate-resistant soybean (Glicine max) to trimethylsulfonium and isopropylamine salts of glyphosate. Weed Technnol 15:745-749.

Lee TT (1981). Effects of glyphosate on synthesis and degradation of chlorophyll in soyabean and tobaco cells. Weed Research 21:161-164.

Mannlerof M, Tuvesson S, Steen P, Tenning P (1997). Transgenic sugar beet tolerant to glyphosate. Euphytica 94:83-91.

Monaco TJ, Weller SC, Ashton FM (2002). Borates. In Weed Science: Principles and Practices. 4th ed. New Yourk, J Wiley, 374-375.

Mueller TC, Massey JH, Hayes RM, Main CL, Stewart CN (2003). Shikimate accumulation in both glyphosate-sensitive and glyphosate-resistant horseweed (Conyza canadensis L. Crong.). J Agric Food Chem 51:680-684.

Padgette SR, Kolacz KH, Delannay X (1995). Development, identification and characterization of a glyphosate-tolerant soybean line. Crop Science 35:1451-1461.
Pavlovic D, Reinhardt C, Elezovic I, Vrbnicanin S (2011). Identification of glyphosate resistance in Lolium rigidum Gaudin. Pest Phyto 26:393-399.

Powles SB, Preston C (2006). Evolved glyphosate resistance in plants: Biochemical and genetic basis of resistance. Weed Technol 20:282-289.

Reddy KN, Rimando AM, Duke SO (2004). Aminomethylphosphonic acid, a metabolite of glyphosate, causes injury in glyphosate-treated, glyphosate-resistant soybean. J Agric Food Chem 52:5139-5143.

Ryerse JS, Downer RA, Sammans RD (2004). Effect of glyphosate spray droplets on leaf cytology in Abutilon theophrasty. Weed Science 52:302-309.

Satchivi NM, Wax LM, Stoller EW, Briskin PD (2000). Adsorption and trnslocation of glyphosate isopropylamine and trimethylsulfonium salts in Abutilon theophrasty and Setaria faberi. Weed Science 48:675-679.

Siehl DL (1997). Inhibitors of EPSP synthase, glutamine synthetase and histidine synthesis, p. 37-67. In: Roe RM (ed). Herbicide Toxicity: Toxigology, Biochemistry and Molecular Biology. Amsterdam, Netherlands: IOS.

Singh BJ, Shaner DL (1998). Rapid determination injury to plants and identification of glyphosate-resistant plants. Weed Technology 12:527-530.

Tuffi Santos LD, Meire ASMR, Ferreira FA, Sant'Anna-Santos BF, Ferreira LR (2007). Morphological responses of different eucalypt clones submitted to glyphosate drift. Environ Exp Bot 59:11-20.

Zobiole LHS, Oliveire RS, Constantin J, Biffer DF (2011). Prevention of RR soybean injures caused by exogenous supply of aminoacides. Planta Daninha 29:195-205. 